\title{
Regulation of transient receptor potential (TRP) channels by phosphoinositides
}

\author{
Tibor Rohacs $\cdot$ Bernd Nilius
}

Received: 26 March 2007 / Accepted: 13 April 2007 /Published online: 4 May 2007

(C) Springer-Verlag 2007

\begin{abstract}
This review summarizes the modulation of transient receptor potential (TRP) channels, by phosphoinositides. TRP channels are characterized by polymodal activation and a surprising complexity of regulation mechanisms. Possibly, most if not all TRP channels are modulated by phosphoinositides. Modulation by phosphatidylinositol 4,5-biphosphate $\left(\mathrm{PIP}_{2}\right)$ has been shown in detail for TRP vanilloid (TRPV) 1, TRPV5, TRP melastatin (TRPM) 4, TRPM5, TRPM7, TRPM8, TRP polycystin 2, and the Drosophila TPR-like (TRPL) channels. This review describes mechanisms of modulation of TRP channels mainly by $\mathrm{PIP}_{2}$ and discusses some future challenges of this fascinating topic.
\end{abstract}

Keywords TRP. PIP $2 \cdot \operatorname{PtdIns}(4,5) \mathrm{P}_{2} \cdot$ TRPV $\cdot$ TRPM . TRPC · TRPA

\section{Introduction}

Transient receptor potential (TRP) channels are the most recently discovered major ion channel superfamily. They share similar topology with voltage-gated ion channels; they likely have six transmembrane segments per subunit and

T. Rohacs $(\bowtie)$

Department of Pharmacology and Physiology,

University of Medicine and Dentistry of New Jersey-

New Jersey Medical School,

Newark, NJ 07103, USA

e-mail: tibor.rohacs@umdnj.edu

\section{B. Nilius}

Department of Molecular Cell Biology, Division of Physiology,

Laboratory of Ion Channel Research, KU Leuven,

Campus Gasthuisberg, Herestraat 49, bus 802,

3000 Leuven, Belgium probably form homo- or heterotetramers. Indeed, most TRP channels are regulated by voltage, although their voltage dependence is less steep than that of classical voltage-gated channels [67]. The regulation of TRP channels is polymodal. Regulatory factors include physical factors such as temperature, voltage, and mechanical stimuli, chemical factors such as $\mathrm{pH}$ and ions, mainly $\mathrm{Ca}^{2+}$ and $\mathrm{Mg}^{2+}$, and various signaling pathways including phospholipase $\mathrm{C}$ and various kinases. Many aspects of TRP channel regulation have been extensively reviewed $[15,60,66,70,71]$, including their regulation by lipids $[27,28,82]$. In a recent review, one of the authors discussed phosphoinositide regulation of TRP channels, in the context of general aspects of ion channel regulation by phosphatidylinositol 4,5-biphosphate $\left(\mathrm{PIP}_{2}\right)$ [82]. This review will place $\mathrm{PIP}_{2}$ regulation of specific TRP channels into the context of their regulation by other factors as well as their biological function.

TRP channels have fascinated many scientists, ever since their discovery. We all encounter TRP channels in our daily lives on a regular basis. When we brush our teeth in the morning with a menthol-containing toothpaste, the resulting cool feeling is caused by the activation of TRP melastatin (TRPM) 8. Then, throughout the day, changes in ambient temperature are mainly sensed by channels in the TRPM and TRP vanilloid (TRPV) families [18]. At lunch or dinner, spices such as chili peppers [11], oregano [109], wasabi, horseradish, or mustard [37] all activate various TRP channels that lead to the familiar sensations we all know very well. A large number of other biological functions also involve TRP channels as key players. Calcium and magnesium absorption from the kidneys and intestines [32], $\mathrm{Ca}^{2+}$ signaling by hormones, and neurotransmitters that activate PLC, cell death, and vision in invertebrates [29] all involve TRP channels. There are also a number of diseases that are caused by mutations in TRP channels, the most common of 
them is polycystic kidney disease (PKD), for detailed reviews, see $[38,66,70]$.

Seemingly, there is nothing in common that would hold this variety of biological functions together. There is an emerging attention to the role of phosphoinositides, especially $\mathrm{PIP}_{2}$, in the regulation of TRP channels. It is hard to tell if $\mathrm{PIP}_{2}$ is a common regulator of TRP channel, but even if it is not, it is important for many of them. Of course, the TRP channels are not unique in this respect ([31, 95], see also all the other reviews in this issue).

When studying phosphoinositide regulation of any biological process, including ion channels, there are several factors that need to be kept in mind. First of all, the lipids in the plasma membrane are essentially in two dimensions where "concentration" cannot be interpreted in the classical sense. Second, several phosphoinositides especially PIP $_{2}$ and phosphatidylinositol 4-phosphate (PIP) are found in substantial levels in resting cells, and their concentrations may decrease upon the activation of phospholipase C (PLC) but are unlikely to reach zero under physiological conditions. This makes the apparent affinity of a given ion channel for phosphoinositides a very important determinant of their regulation; that is, a channel with high affinity for $\mathrm{PIP}_{2}$ may not be inhibited by a moderate $\mathrm{PIP}_{2}$ depletion, whereas a channel with low affinity is inhibited. Third, phosphoinositides are local signaling molecules that are not distributed homogenously in the plasma membrane; rather, it is likely that specific PIP "microdomains" or "pools" exist [57]. These questions were discussed in detail recently in the context of $\mathrm{PIP}_{2}$ regulation of TRP channels [82].

This review will discuss the available experimental tools, including recently developed ones, to study phosphoinositide regulation of ion channels, before discussing the specific data on TRP channels.

\section{Tools to study phosphoinositide regulation of ion channels}

Perhaps the simplest and most direct evidence for $\mathrm{PIP}_{2}$ regulation of an ion channel is to test the effect of the lipid in excised patches [34, 65, 84, 86, 87, 97]. Keep in mind, however, that the patch membrane already contains endogenous $\mathrm{PIP}_{2}$, which in the case of a channel with high $\mathrm{PIP}_{2}$ affinity may already produce saturated activity. The effect of exogenous $\mathrm{PIP}_{2}$ in this case can only be determined if endogenous $\mathrm{PIP}_{2}$ levels are substantially decreased. This may happen spontaneously, by letting the patch stand in an adenosine triphosphate (ATP)-free solution in the inside-out configuration, thus allowing endogenous lipid phosphatases to dephosphorylate PIP $_{2}$. This phenomenon causes the well known "rundown" of current activity for many $\mathrm{PIP}_{2}$ sensitive channels $[30,34,97]$. The putative lipid phospha- tases can be inhibited by a cocktail containing fluoride, vanadate, and pyrophosphate (FVPP) [34, 84]. The activity of the phosphatases on the other hand can be enhanced by adding millimolar concentrations of $\mathrm{Mg}^{2+}$ [34]. Similarly, micromolar concentrations of $\mathrm{Ca}^{2+}$ can activate PLC in the excised patches, also leading to a decrease in $\mathrm{PIP}_{2}$ levels [34, 65]. Note that although both phosphatases and PLC reduce $\mathrm{PIP}_{2}$ and probably PIP levels, their end products are different; phosphatases remove only the phosphates, producing PI and PIP, whereas PLC removes the whole head group, thus producing diacylglycerol (DAG) and inositol triphosphate $\left(\mathrm{IP}_{3}\right)$.

Endogenous $\mathrm{PIP}_{2}$ levels can also be reduced using various $\mathrm{PIP}_{2}$-chelating agents, such as poly-lysine [84, 86], $\mathrm{PIP}_{2}$ antibody [30, 34, 84], and neomycin [34]. Unfortunately, there is not a single $\mathrm{PIP}_{2}$ scavenger that is ideal to use. Poly-lysine and neomycin are not specific; they probably also screen the charges of other negatively charged lipids, such as phosphatidylinositol and phosphatidylserine. The $\mathrm{PIP}_{2}$ antibody on the other hand is supposed to be specific to $\mathrm{PIP}_{2}$ over other negatively charged lipids, but it works much less reliably that poly-Lys [84]. Although there are numerous older [34, 97] and more recent reports [48] on the effectiveness of the $\mathrm{PIP}_{2}$ antibody, there are also reports on the lack of its effects on ion channels that are shown to be $\mathrm{PIP}_{2}$ sensitive using other methods $[22,50]$. Considering the reluctance of many investigators to include negative data in publications, the incidence of the lack of effect of the $\mathrm{PIP}_{2}$ antibody is probably higher.

Once ready to apply phosphoinositides to the patch, we have several choices. The first reports used either $\mathrm{PIP}_{2}[30$, 97] or mixed phosphoinositides [23] purified from biological sources, usually bovine brain. These contain a mixture of acyl chains, the most common combination being arachidonyl-stearyl (AASt). Synthetic dipalmitoyl (DiP) $\mathrm{PIP}_{2}$ is also available from many vendors; it is supposedly more stable than the natural form and has similar effects to AASt $\mathrm{PIP}_{2}$ in most cases. Although, be cautioned that on Kir3.1/3.4 (GIRK) channels, DiP PIP 2 was substantially less effective than AASt [83].

Another choice, with increasing popularity, is the synthetic dioctanoyl $\left(\mathrm{diC}_{8}\right) \mathrm{PIP}_{2}[65,83,86]$. This lipid is water soluble, and it activates ion channels in a quickly reversible fashion, as opposed to DiP or AASt $\mathrm{PIP}_{2}$, which activate most ion channels essentially irreversibly [84]. An important advantage of $\mathrm{diC}_{8} \mathrm{PIP}_{2}$ is that dose-response measurements can be performed and specificity profiles of phosphoinositide effects can easily be evaluated. Apparent affinities obtained with $\mathrm{diC}_{8} \mathrm{PIP}_{2}$ dose-response measurements show excellent correlation with $\mathrm{PIP}_{2}$ affinities obtained with other methods such as $\mathrm{PIP}_{2}$ antibody or poly-Lys inhibition kinetics, inhibition by $\mathrm{PIP}_{2}$ depletion, 
and direct binding $[19,51,110]$. Specificity profiles obtained by $\mathrm{diC}_{8}$ phosphoinositide analogues also show excellent correlation with specificity profiles using natural or long acyl-chain synthetic phosphoinositides [41, 83, 85].

A more recently described alternative is the PLC resistant analogue of $\mathrm{PIP}_{2}$ that was shown to activate TRPM4 [111]. Again, just as with $\mathrm{PIP}_{2}$ scavengers, there is not a single ideal phosphoinositide to use in excised patches. The caveat of the long acyl chain phosphoinositides is that usually they exert their effects slowly and they accumulate in the patch membrane eventually reaching concentrations that are probably much higher than those that occur naturally. The $\mathrm{diC}_{8}$ phosphoinositide analogues obviously have different physicochemical characteristics from those of the natural lipid, and rigorous comparison of the effects of $\mathrm{DiC}_{8}$ phosphoinositides and the natural lipids have not yet been performed for most channels. There is only one report so far on the effect of PLCresistant $\mathrm{PIP}_{2}$ on ion channels, and it showed PLCresistant PIP $_{2}$ analogues [111] activated TRPM4 in excised patches.

$\mathrm{PIP}_{2}$ levels can also be modified indirectly in excised patches, by applying either enzymes that modify their levels or substrates for such enzymes. Providing Mg-ATP for endogenous lipid kinases prevents rundown or reactivates many PIP $_{2}$-sensitive ion channels [34, 97], including TRP channels [48, 65]. Purified phosphatidylinositol-specific PLC has also been used by several laboratories to deplete $\mathrm{PIP}_{2}$ from the intracellular surface of excised patches [22, 30].

Phosphoinositides can also be directly applied in whole-cell patch clamp experiments by dialyzing them through the patch pipette. This approach has been successfully used to demonstrate $\mathrm{PIP}_{2}$ sensitivity of several ion channels, including TRP channels [87]. Another way of directly applying phosphoinositides in intact cells is to use various shuttle molecules such as neomycin [72]. The caveat of this approach is that the shuttle molecules themselves bind phosphoinositides and thus may also alter endogenous lipid levels.

In intact cells, we can activate PLC to decrease $\mathrm{PIP}_{2}$ levels by stimulating endogenous or overexpressed cell surface receptors [86, 87]. Activating PLC, however, also generates $\mathrm{IP}_{3}$ and DAG, thus leading to a $\mathrm{Ca}^{2+}$ release and activation of protein kinase $\mathrm{C}$ (PKC). The effects of the downstream molecules are sometimes difficult to differentiate from that of decreased PIP $_{2}$ levels. Lipid phosphatases and kinases do not have such obvious activators; thus, their effects can either be studied by overexpressing them [12, 92] or inhibiting them using pharmacological tools [62]. Overexpression of kinases or phosphatases can be achieved using a constitutive promoter $[86,92]$ or a tetracyclineinducible system $[12,65]$. Unfortunately, the available inhibitors of phosphatidylinositol 4-kinases (PI4K), wortmannin, and phenylarsine oxide are not very specific [3].
Pharmacological tools to inhibit lipid phosphatases and phosphatidylinositol 4-phosphate 5-kinase (PIP5K) are even more limited. When overexpressing lipid phosphatases and kinases, we have to keep in mind that long-term changes in phosphoinositides may induce nonspecific changes in the cellular environment that may also affect channel activity.

Finally and more recently, a novel approach was introduced to the study of phosphoinositide signaling. It is based on the rapamycin-induced heterodimerization of the rapamycin binding domain of mTOR and FKBP12, which was successfully used earlier to manipulate small guanosinetriphosphate-binding proteins at the plasma membrane [36]. This approach was utilized concurrently by two laboratories to rapidly and selectively modify PIP $_{2}$ levels in the plasma membrane, without activating other signaling pathways and study the regulation of ion channels [56]. Rapamycininduced translocation of the phosphatase domain of type-IV 5-phosphatase inhibited the activity of TRPM8, showing that the activity of these channels depends on the presence of $\mathrm{PIP}_{2}$ [104]. A similar approach was also utilized concurrently to study the regulation of KCNQ channels [96].

In summary, a variety of tools is available to study phosphoinositide regulation of ion channels; keeping their advantages and caveats in mind, their combined use is necessary to establish regulatory roles for these lipids on ion channels.

\section{TRPC channels}

Canonical transient receptor potential (TRPC) channels are the closest mammalian homologues of the Drosophila TRP channel (Table 1). TRPCs, just like most other TRP channels, are nonselective cation channels that also conduct $\mathrm{Ca}^{2+}$. Although they are generally assumed to mediate $\mathrm{Ca}^{2+}$ influx, they have substantial conductance of $\mathrm{Na}^{+}$ions; thus, they also depolarize the cells, which should also be considered [21] when discussing their physiological roles. Both mammalian TRPCs and the Drosophila TRP/TRP-like (TRPL) complex are activated by cell surface receptors that activate PLC. PLC hydrolyzes $\mathrm{PIP}_{2}$ to form $\mathrm{IP}_{3}$ and DAG. $\mathrm{IP}_{3}$ releases $\mathrm{Ca}^{2+}$ from internal stores, and $\mathrm{Ca}^{2+}$ activates a wide variety of biological processes. Given the finite capacity of the internal stores, a secondary $\mathrm{Ca}^{2+}$ influx from the extracellular space is necessary for sustained $\mathrm{Ca}^{2+}$ signaling [80]. The search for the mechanism of this enhanced $\mathrm{Ca}^{2+}$ influx undoubtedly accelerated the early progress in the cloning and study of mammalian TRP channels [115]. TRPC channels are activated by PLCcoupled agonists, but the exact mechanism that couples PLC activation to channel opening is not really clear even now. 
Table 1 Some properties of the TRPC family members

\begin{tabular}{|c|c|c|c|}
\hline & $\begin{array}{l}\text { Selectivity } \\
P_{\mathrm{Ca}} / P_{\mathrm{Na}}\end{array}$ & Proposed activation mechanisms & $\begin{array}{l}\text { Effect of phosphoinositides } \\
\text { (PIPs) }\end{array}$ \\
\hline $\begin{array}{l}\text { TRPC1, } \\
\text { ENSG00000144935 }\end{array}$ & Nonselective & $\begin{array}{l}\text { PLC, 1-oleoyl-2-acetyl-sn-glycerol (OAG), mechanical (stretch), } \\
\text { phosphoinositide-3 kinase (PI3K), calmodulin, receptor tyrosine- } \\
\text { kinases (RTK)-PLC } \gamma \text {. upregulated by PKC, NO?, store depletion? }\end{array}$ & $?$ \\
\hline $\begin{array}{l}\text { TRPC2, } \\
\text { ENSMUSG00000058020 }\end{array}$ & 2.7 & PLC, DAG, store depletion? & $?$ \\
\hline $\begin{array}{l}\text { TRPC3, } \\
\text { ENSG00000138741 }\end{array}$ & 1.6 & PLC, DAG, OAG, src TK, $\mathrm{IP}_{3}$, intracellular $\mathrm{Ca}^{2+}$, store depletion & $?$ \\
\hline $\begin{array}{l}\text { TRPC4, } \\
\text { ENSG00000100991 }\end{array}$ & $1.1-7.7$ & PLC, . GTP $\gamma \mathrm{S}$, micromolar $\mathrm{La}^{3+}$, store depletion? & ? \\
\hline $\begin{array}{l}\text { TRPC5, } \\
\text { ENSG00000072315 }\end{array}$ & $1.8-9.0$ & $\begin{array}{l}\text { PLC, . GTP } \gamma \mathrm{S} \text {, receptor operated, lysophosphatidylcholine } \\
\text { (LPC), micromolar } \mathrm{La}^{3+} \text { or } \mathrm{Gd}^{3+} \text {, store depletion?, PIP } 5 \mathrm{~K}, \text { Rho } \\
\text { GTPases (e.g., Rac1), PI3K, myosin light chain kinase (MLCK), } \\
\text { NO nitrosylation of pore cysteines }\end{array}$ & $\begin{array}{l}\text { PIPs play a role in traffic to the } \\
\text { plasma membrane [5]. }\end{array}$ \\
\hline $\begin{array}{l}\text { TRPC6, } \\
\text { ENSG00000137672 }\end{array}$ & 5 & $\begin{array}{l}\text { PLC. DAG, OAG, Src, 20-hydroxyeicosatetraenoic acid ( } 20- \\
\text { HETE), tyrosine kinase Fyn, } \mathrm{Ca}^{2+} \text {-Calmodulin kinase II (CamK- } \\
\text { II), mechano-activated, } \mathrm{AlF}_{4}^{-}, \operatorname{PtdIns}(3,4,5) \mathrm{P}_{3} \text { activates }[102]\end{array}$ & $\begin{array}{l}\text { C-terminus binds } \\
\text { phosphoinositides competing } \\
\text { with calmodulin [42] }\end{array}$ \\
\hline $\begin{array}{l}\text { TRPC7, } \\
\text { ENSG00000069018 }\end{array}$ & 2 & PLC, DAG, OAG, 20-HETE, store depletion & $?$ \\
\hline
\end{tabular}

For more information see http://www.ensembl.org/, http://clapham.tch.harvard.edu/, Special Issues "TRP channels: facts, fiction, challenges," Cell Calcium 33, 2003, and "Functional role of TRP channels" Pflügers Arch 451, 2005; for detailed reviews see also references [15, 25, 63, 66, 69, 73, 108]

One widely used experimental paradigm to study this question is the Drosophila eye. There, DAG or some of its metabolites are clearly involved in opening the channel. As the Drosophila TRPL channel is inhibited by $\mathrm{PIP}_{2}$ in excised patches [22], a simultaneous depletion of $\mathrm{PIP}_{2}$ may also contribute to the full activation of the TRP/TRPL complex [28]. The involvement of various lipids in signal transduction in invertebrate vision has been extensively reviewed $[27,28]$.

Mammalian TRPC3, TRPC6, and TRPC7 are activated by DAG. This mechanism provides a rational basis for their activation. TRPC4 and TRPC5 are not activated by DAG. $\mathrm{PIP}_{2}$ depletion could serve as a mechanism for their activation, but an inhibitory effect of $\mathrm{PIP}_{2}$ has not yet been reported on these channels. TRPC5 was reported to be activated by the epidermal growth factor (EGF) via vesicular translocation to the plasma membrane [5]. Both phospoinositide 3-kinase and PIP5K were required for this phenomenon, showing the involvement of phosphoinositides. As phosphoinositides are important for membrane trafficking, similar mechanisms may also regulate the activity of other ion channels. These indirect effects of phosphoinositides should also be considered in addition to the presumably direct effects of the lipids on ion channels.

A recent report showed that in TRPC6, a C-terminal calmodulin-binding domain also binds phosphoinositides [42]. The lipids compete with calmodulin for binding, PtdIns $(3,4,5) \mathrm{P}_{3}$ being the most effective. It was proposed that the competition between phosphoinositides and calmodulin plays a role in the regulation of TRPC6 channels [42]. Extracellular application of PtdIns $(3,4,5) \mathrm{P}_{3}$ was also shown to induce TRPC6 activity [102]. Biochemical evidence for competition between calmodulin and phosphoinositides was also provided for other channels including TRPV1, voltagegated $\mathrm{Ca}^{2+}$ channels, and $\mathrm{KCNQ} \mathrm{K}^{+}$channels [42]. Competition of phosphoinositides with calmodulin has also been extensively discussed for cytoplasmic proteins [57] and was also shown for cyclic-nucleotide-gated channels [7]. Thus, it is possible that this paradigm is a general phenomenon for ion channels and should be considered as a possible regulatory mechanism.

Initially, the prevailing view was that the event that initiates TRPC channel activation is the depletion of internal $\mathrm{Ca}^{2+}$ stores (capacitative or store-operated mechanism) [80, 115]. This was clearly disproved for the activation of the Drosophila TRP channel complex [27], but for mammalian TRPCs, it could be the mechanism of activation in certain cases [81]. A recent development in this field is the cloning of STIM1 [112], which functions as a $\mathrm{Ca}^{2+}$ sensor in the endoplasmic reticulum, and Orail or CRACM1 [24, 105], which probably constitutes the poreforming subunit of the long-sought $I_{\text {CRAC. All three }}$ members of the Orai family have four putative transmembrane regions and show no homology to TRP channels or to any other known ion channels. Interestingly, STIM also interacts with and activates certain TRPC channels $[35,52]$. 
$\mathrm{I}_{\text {CRAC }}$ has been shown to be inhibited by depletion of phosphoinositides [9]. Inspection of the sequences of the three human Orai proteins shows a highly conserved cluster of positively charged residues just before the first putative transmembrane domain, which could serve as phosphoinositide interaction sites, if indeed these channels need phosphoinositides for activity. Interestingly, however, depletion of $\mathrm{PIP}_{2}$ with rapamycin-inducible $\mathrm{PIP}_{2}$ 5-phosphatase did not inhibit thapsigargin-induced $\mathrm{Ca}^{2+}$ entry [104]. In summary, relatively little is known about phosphoinositide regulation of TRPC channels or the recently cloned $\mathrm{I}_{\mathrm{CRAC}}$ channels, but we can expect progress on this field in the near future [64] .

\section{TRPV channels}

Mammalian TRPV channels can be separated into two functionally distinct groups (Table 2). TRPV1-4 channels are all activated by warm temperatures with various thresholds, while some of them are also activated by mechanical stimuli. These four channels are outwardly rectifying, nonselective cation channels, similar to most other TRP channels. They are mainly expressed in sensory neurons. TRPV5 and 6 on the other hand are inwardly rectifying, $\mathrm{Ca}^{2+}$-selective channels. They are expressed mainly in epithelial tissues, such as the kidneys and intestines. Their physiological function is $\mathrm{Ca}^{2+}$ absorption [32]. There are reports of $\mathrm{PIP}_{2}$ regulation of members of both groups.

TRPV1 was the first non-TRPC mammalian TRP channel that was cloned [11]. A quick PubMed search reveals that there are more articles about TRPV1 than any other individual TRP channel. If we extend the search to capsaicin, its specific activator, there are more articles than about all other TRP channels combined. What drives this fascination? There are several factors; clearly, one of them is its involvement in pain sensation [10] and other disease states [70], but its exceedingly complex regulation is certainly another important factor. This complexity also applies to its regulation by phosphoinositides. TRPV1 is activated by warm temperatures, protons, endogenous cannabinoids, depolarization, various lipids, and capsaicin (the pungent

Table 2 Some important properties of the TRPV family members

\begin{tabular}{|c|c|c|c|}
\hline & $\begin{array}{l}\text { Selectivity } \\
P_{\mathrm{Ca}} / P_{\mathrm{Na}}\end{array}$ & Proposed activation mechanisms & $\begin{array}{l}\text { Effect of phosphoinositides } \\
\text { (PIPs) }\end{array}$ \\
\hline $\begin{array}{l}\text { TRPV1, } \\
\text { ENSG00000043316 }\end{array}$ & $\begin{array}{l}\sim 10 \text { (capsaicin } \\
\text { activated } \\
\text { current), } \sim 4 \\
\text { (heat activated } \\
\text { current) }\end{array}$ & $\begin{array}{l}\text { Depolarization, heat }\left(\geq 43^{\circ} \mathrm{C}\right) \text {, low pH }(\leq 5.9) \text {, vanilloids, } \\
\text { endovanilloids, PKC, CamK-II, PI3K, anandamide, nerve } \\
\text { growth factor (NGF), glia-derived growth factor (GDGF), } \\
\text { neurotrophin } 3 \text { (NT3), reducing agents like dithiothreitol } \\
\text { (DTT), sensitization by ethanol, jelly fish toxin, venoms of } \\
\text { the Indian tarantulas contain inhibitor cysteine knot peptides } \\
\text { (ICK), 12/15-hydroperoxyeicosatetraenoic acid (12-( } S) \text { - } \\
\text { HPETE, 15-(S)-HPETE), 5-(S)-HETE, leukotriene } \mathrm{B}_{4}, N \text { - } \\
\text { arachidonoyl dopamine (NADA), protease-activated } \\
\text { receptor } 2 \text { (PAR2), spermine, } 2 \text {-aminoethoxydiphenyl borate } \\
\text { (2-APB), oleoylethanolamide (OEA), protein kinase A } \\
\text { (PKA), PGE } 2 \text { and } \text { PGI }_{2} \text { via their receptor } \mathrm{EP}_{\mathrm{I}} \text { or IP }\end{array}$ & $\begin{array}{l}\mathrm{PIP}_{2} \text { inhibits in intact } \\
\text { cells }[14,53,78] \\
\mathrm{PIP}_{2} \text { activates } \\
\text { excised patches } \\
{[53,93]}\end{array}$ \\
\hline $\begin{array}{l}\text { TRPV2, } \\
\text { ENSG00000154039 }\end{array}$ & $1-3$ & $\begin{array}{l}\text { Noxious heat }\left(>53^{\circ} \mathrm{C}\right) \text {, mechanical (stretch, swelling), PKC, } \\
\text { PI3K, growth factors, insulin-like growth factor } 1 \text { (IGF-1), } \\
\text { head activator (HA), 2-APB }\end{array}$ & $?$ \\
\hline $\begin{array}{l}\text { TRPV3, } \\
\text { ENSG00000167723 }\end{array}$ & 2.6 & Heat $\left(23-29^{\circ} \mathrm{C}\right)$, camphor, $2-\mathrm{APB}$, voltage dependent & $?$ \\
\hline $\begin{array}{l}\text { TRPV4, } \\
\text { ENSG00000111199 }\end{array}$ & $6-10$ & $\begin{array}{l}\text { Moderate heat }\left(>24^{\circ} \mathrm{C}\right) \text {, cell swelling, shear stress, } \\
\text { phospholipase } \mathrm{A}_{2}\left(\mathrm{PLA}_{2}\right) \text { activation, PKC, PAR } \\
\text { anandamide, epoxyeicosatrienoic acid (EETs), } 4 \alpha \text {-phorbol } \\
\text { 12,13-didecanoate ( } 4 \alpha \text {-PDD) and other phorbols, } \\
\text { bisandrographolide A (BAA) from a Chinese herb }\end{array}$ & $?$ \\
\hline $\begin{array}{l}\text { TRPV5, } \\
\text { ENSG00000127412 }\end{array}$ & $>100$ & $\begin{array}{l}\text { Low }\left[\mathrm{Ca}^{2+}\right]_{i} \text {, hyperpolarization, voltage dependent block by } \\
\mathrm{Mg}^{2+} \text {, serum- and glucocorticoid-dependent kinase } 1 \\
(\mathrm{SGK} 1) \text {, serine/threonine kinase WNK4 }\end{array}$ & $\mathrm{PIP}_{2}$ activates $[47,86]$ \\
\hline $\begin{array}{l}\text { TRPV6, } \\
\text { ENSG00000165125 }\end{array}$ & $>100$ & $\begin{array}{l}\text { Low }\left[\mathrm{Ca}^{2+}\right]_{i} \text {, hyperpolarization, voltage dependent block by } \\
\mathrm{Mg}^{2+}\end{array}$ & $?$ \\
\hline
\end{tabular}

For references for channel names, numbering, and additional information, see legend to Table 1 
compound of chili peppers). All the latter compounds induce a dramatic shift of the TRPV1 activation curve towards negative potentials $[67,106,108]$. TRPV1 is involved in nociception, the sensation of pain. A drop in $\mathrm{pH}$ that often accompanies tissue injury is one factor that contributes to activation of TRPV1 in these circumstances [100].

Another event that is involved in the activation of TRPV1 by painful stimuli is the release of proinflammatory substances upon tissue damage. These factors include bradykinin, extracellular ATP, and chemokines. Many of these factors activate PLC. We all know that an inflamed area feels warmer than normal and even moderately warm temperatures or other innocuous stimuli can feel painful. This phenomenon, thermal hyperalgesia, at least in part, is caused by the increased sensitivity of TRPV1. The sensitization of TRPV1 has been shown to involve PKC [6], and it was also proposed that $\mathrm{PIP}_{2}$ inhibits these channels and relief from this inhibition leads to the sensitized state of these channels [14].

The idea that PIP $_{2}$ inhibits TRPV1 was based on indirect measurements; the effects of the lipid were not tested in excised patches. Note that sensitization mainly occurs at moderate stimuli; the manifestation of sensitization is generally a left shift in the dose response to capsaicin and $\mathrm{pH}[14,101]$. In other words, if there is an inhibitory effect of $\mathrm{PIP}_{2}$, it is mainly prevalent at low stimulation strength, such as low capsaicin concentration. The region responsible for inhibition by $\mathrm{PIP}_{2}$ was proposed to be in the very distal $\mathrm{C}$ terminus of TRPV1, which shares no homology to the same region of any other TRP channel [78]. Consistent with the role of the distal $\mathrm{C}$ terminus in $\mathrm{PIP}_{2}$ inhibition, it was found that when the $\mathrm{C}$ terminus of TRPM8 was replaced with the $\mathrm{C}$ terminus of TRPV1, the chimeric channel was inhibited by $\mathrm{PIP}_{2}$ dialyzed through the patch pipette [8]. As all other mammalian TRP channels that were tested so far are activated by $\mathrm{PIP}_{2}$, the inhibitory effect of $\mathrm{PIP}_{2}$ seems unique to TRPV1. Indeed, it was recently reported that $\mathrm{PIP}_{2}$ activates TRPV1 in excised patches [53, 93]. How can we put these data together? It is likely that TRPV1 needs PIP 2 to be open, just like most other TRP channels. Under certain circumstances, such as low capsaicin concentrations, however, $\mathrm{PIP}_{2}$ may partially inhibit TRPV1, leading to a bell-shaped dependence on $\mathrm{PIP}_{2}$ concentration [53].

What is the relevance of the activating effect of $\mathrm{PIP}_{2}$ on TRPV1? TRPV1 channels undergo desensitization in response to high concentrations of capsaicin in the presence of extracellular $\mathrm{Ca}^{2+}$. This phenomenon is likely to play an important role in the paradoxical use of capsaicin as a local analgesic [89]. This phenomenon was shown to involve the calcium-sensitive protein phosphatase calcineurin [58]. Inhibition of desensitization by calcineurin inhibitors was partial [58]. It was shown earlier that resynthesis of $\mathrm{PIP}_{2}$ is required for recovery from desensitization [49], which was difficult to put together with the originally published inhibition of TRPV1 by PIP 2 . In view of the recent reports showing activation of TRPV1 by $\mathrm{PIP}_{2}[53,93]$, the role of $\mathrm{PIP}_{2}$ depletion in desensitization seems a feasible mechanism. We have indeed found that interfering with depletion of $\mathrm{PIP}_{2}$ either by inhibiting PLC with U73122 or dialyzing $\mathrm{PIP}_{2}$ or PIP through the patch pipette in whole-cell experiments inhibited desensitization of TRPV1 [53]. Note that desensitization of TRPV1 is usually studied at high capsaicin concentrations, where the potential inhibitory effect of $\mathrm{PIP}_{2}$ is likely not to be present.

The only other TRPV channel that has been reported to be regulated by $\mathrm{PIP}_{2}$ is TRPV5, which is activated by PIP $[47,86]$. It was reported that $\mathrm{PIP}_{2}$ relieves the inhibition of TRPV5 by $\mathrm{Mg}^{2+}$. $\mathrm{PIP}_{2}$ decreases the sensitivity of the channel to inhibition by $\mathrm{Mg}^{2+}$, which probably binds to a conserved aspartate (D542) residue in the selectivity filter, causing not only fast, voltage-dependent inhibition but also slow inhibition. The slow inhibition is abolished by $\mathrm{PIP}_{2}$, but the activation of TRPV5 by $\mathrm{PIP}_{2}$ was not dependent on $\mathrm{Mg}^{2+}$. For detailed description of the $\mathrm{Mg}^{2+}$ block of the highly homologous TRPV6 channel, see [107]. Interestingly, a somewhat similar mechanism was proposed for TRPM7 ([39], see later). As $\mathrm{Mg}^{2+}$ is found in the cytoplasm at a relatively high concentration and it can interfere with $\mathrm{PIP}_{2}$ activation of ion channels, this ion should be considered when studying regulation of other ion channels by phosphoinositides. As representative members of the two groups of TRPVs that are activated by $\mathrm{PIP}_{2}$, it is quite likely that PIP $_{2}$ is a general activator of TRPV channels, but we have to wait for further publications to confirm this.

\section{TRPM channels}

TRPM channels are the most recently cloned and most diverse members of the mammalian TRP family (Table 3). There are not one or two simple themes as for TRPCs and TRPVs that could describe their functions. There are four members of the TRPM family that have been reported to be activated by PIP $_{2}$; these are TRPM7 [26, 87], TRPM5 [50], TRPM8 [48, 86], and TRPM4 [65, 114]. We will provide some background on the functions of these four channels in the context of their phosphoinositide regulation. It is likely that $\mathrm{PIP}_{2}$ is a general activator of TRPM channels, but again we have to wait for further data to confirm this.

TRPM7 is the first mammalian TRP channel that was reported to be activated by $\mathrm{PIP}_{2}$ [87]. TRPM7 is an intriguing channel. It has an atypical kinase domain at the end of its $\mathrm{C}$ terminus, similarly to TRPM6. The exact function of this kinase domain and its role in channel regulation is not yet clear. It is hard to describe the functional role of TRPM7 in one sentence, as multiple 
Table 3 Some important properties of the TRPM family members

\begin{tabular}{|c|c|c|c|}
\hline & $\begin{array}{l}\text { Selectivity } \\
P_{\mathrm{Ca}} / P_{\mathrm{Na}}\end{array}$ & Proposed activation mechanisms & Effect of phosphoinositides (PIPs) \\
\hline $\begin{array}{l}\text { TRPM1, } \\
\text { ENSG00000134160 }\end{array}$ & n.d. & $\begin{array}{l}\text { Translocation, microphthalmia-associated transcription factor } \\
\text { (MITF) induced expression }\end{array}$ & ? \\
\hline $\begin{array}{l}\text { TRPM2, } \\
\text { ENSG00000142185 }\end{array}$ & $0.5-1.6$ & $\begin{array}{l}\text { ADP-ribose, cyclic ADP-ribose at higher temperatures, } \\
\text { nicotinamide adenine dinucleotide (NAD), heat, } \mathrm{H}_{2} \mathrm{O}_{2} \text { and } \\
\text { other reactive oxygen species (ROS), poly(ADP)ribose } \\
\text { polymerase-1 (PARP-1), } \mathrm{Ca}^{2+}, \mathrm{NAD} \text { dependent deacetylases } \\
\text { sirtuins }\end{array}$ & $?$ \\
\hline $\begin{array}{l}\text { TRPM3, } \\
\text { ENSG00000083067 }\end{array}$ & $1.6-2.0$ & Cell swelling, store depletion? D-erythrosphingosine & $?$ \\
\hline $\begin{array}{l}\text { TRPM4, } \\
\text { ENSG00000130529 }\end{array}$ & $\begin{array}{l}\text { Selective for } \\
\text { monovalent } \\
\text { cations }\end{array}$ & $\begin{array}{l}\text { Elevated }\left[\mathrm{Ca}^{2+}\right]_{i} \text {, ATP, PKC, decavanadate, voltage dependent, } \\
\text { heat, 3,5-bis(trifluoromethyl)pyrazole (BTP2) }\end{array}$ & $\mathrm{PIP}_{2}$ activates $[65,114]$ \\
\hline $\begin{array}{l}\text { TRPM5, } \\
\text { ENSG00000070985 }\end{array}$ & $\begin{array}{l}\text { Selective for } \\
\text { monovalent } \\
\text { cations }\end{array}$ & Elevated $\left[\mathrm{Ca}^{2+}\right]_{i}$, voltage dependent, heat & $\mathrm{PIP}_{2}$ activates $[50]$ \\
\hline $\begin{array}{l}\text { TRPM6, } \\
\text { ENSG00000119121 }\end{array}$ & $\mathrm{P}_{\mathrm{Mg}} / \mathrm{P}_{\mathrm{Na}} \sim 6$ & Decreased $\left[\mathrm{Mg}^{2+}\right]_{i}, 2$-APB & ? \\
\hline $\begin{array}{l}\text { TRPM7, } \\
\text { ENSG00000092439 }\end{array}$ & 3 & $\begin{array}{l}\text { Decreased }\left[\mathrm{Mg}^{2+}\right]_{i}, \mathrm{Mg}-\mathrm{ATP}, \mathrm{CAMP}, \mathrm{G} \text { proteins, } \\
\text { shear stress, membrane translocation, PARP }\end{array}$ & $\begin{array}{l}\mathrm{PIP}_{2} \text { activates }[26,87] \text { challenged }[43 \\
98] ; \text { role in traffic to the plasma } \\
\text { membrane }[40]\end{array}$ \\
\hline $\begin{array}{l}\text { TRPM8, } \\
\text { ENSG000000144481 }\end{array}$ & $1-3$ & $\begin{array}{l}\text { Depolarization, cold }\left(8-28^{\circ} \mathrm{C}\right) \text {, menthol, icilin, } \mathrm{Ca}^{2+} \text {, increased } \\
\text { intracellular } \mathrm{pH}\end{array}$ & $\mathrm{PIP}_{2}$ activates $[48,86]$ \\
\hline
\end{tabular}

For references for channel names, numbering, and additional information, see legend to Table 1. For details and references see legend Table 1.

and quite diverse functions have been attributed to it. Deletion of TRPM7 in mice is embryonically lethal (A. G. Ryazanov, personal communication), suggesting important functions in fundamental processes.

TRPM7 channels conduct not only $\mathrm{Ca}^{2+}$ and monovalent cations but also $\mathrm{Mg}^{2+}$. It was proposed that TRPM7 functions as the major cellular $\mathrm{Mg}^{2+}$ uptake mechanism [91]. TRPM7 knockout cells have severely altered $\mathrm{Mg}^{2+}$ uptake mechanism; the residual $\mathrm{Mg}^{2+}$ transport is provided by the solute transporter SLC41 A2 [88]. Intracellular $\mathrm{Mg}^{2+}$ inhibits TRPM7, which may serve as a negative feedback mechanism to inhibit $\mathrm{Mg}^{2+}$ uptake when the cell has enough $\mathrm{Mg}^{2+}$. Under conditions of low intracellular $\mathrm{Mg}^{2+}$, relief from this inhibition may open the channel to restore $\mathrm{Mg}^{2+}$ levels. It has been proposed that $\mathrm{Mg}^{2+}$ inhibits these channels via screening of the charges in $\mathrm{PIP}_{2}$ [39]. TRPM7 has also been shown to be involved in cell death [1], neurotransmitter release [40], cell adhesion [94], and transport of trace metals [59].

TRPM7 has been proposed to be inhibited by PLCmediated $\mathrm{PIP}_{2}$ hydrolysis [87], but this was challenged later by proposing that cyclic adenosine monophosphate and protein kinase A were the major regulators of TRPM7 and Gq-coupled receptors played only a minor role [98]. This contradiction has been discussed in a previous review on this topic [82]; therefore, we will not discuss it in detail here. An interesting recent addition to this debate is the finding that bradykinin acting through a PLC-coupled receptor activates TRPM7 in the perforated patch configuration [43]. The same report confirms previous findings that PLC activation inhibits TRPM7 in the whole-cell configuration, if $\mathrm{Mg}^{2+}$ is not provided in the pipette solution. Providing $\mathrm{Mg}^{2+}$ in the pipette solution reconstituted the activating effect of PLC. The mechanism of the activation of TRPM7 by bradykinin and the involvement of $\mathrm{PIP}_{2}$ was not examined. It would be an interesting hypothesis to test if $\mathrm{PIP}_{2}$ has different effects on TRPM7 depending on the $\mathrm{Mg}^{2+}$ concentration. Note that it was proposed that bradykinin receptor stimulation may not appreciably alter membrane $\mathrm{PIP}_{2}$ levels in contrast to muscarinic stimulation, as it may also activate PI4 kinase that could offset the decrease in $\mathrm{PIP}_{2}$ levels induced by PLC [17]. In native myocardial cells, $\mathrm{PIP}_{2}$ is required for maintaining the activity of a cardiac channel (the $\mathrm{Mg}^{2+}$-inhibited cation channel), which is probably TRPM7 [26].

Interestingly, TRPM7 is present in synaptic vesicles and forms a complex with synapsin I and synaptotagmin I and directly binds to snapin. PIP $_{2}$ seems to target these vesicles to the plasma membrane, and it may also be responsible for TRPM7 activation upon fusion of the synaptic vesicle (devoid of $\mathrm{PIP}_{2}$ ) to the plasma membrane (contains $\mathrm{PIP}_{2}$ ). Likely, TRPM7 is involved in acetylcholine release: The influx of cations into the vesicles via vesicle-attached TRPM7 may mediate an influx of counter-ions, which facilitate acetylcho- 
line release from a negatively charged site in an ion exchange matrix, probably proteoglycans $[40,61]$.

TRPM4 and TRPM5 are nonselective cation channels that have negligible $\mathrm{Ca}^{2+}$ permeabilities $[33,45,76]$. Both are activated by an increase in intracellular $\left[\mathrm{Ca}^{2+}\right]$. TRPM5 was first described in taste tissue [75]; $\mathrm{TRPM}^{-/-}$mice show markedly diminished [16] or no responses [113] to bitter, sweet, and umami tastes. Interestingly, TRPM5 is also inhibited by cold temperatures, and this effect is responsible for the thermal sensitivity of sweet taste [99]. The technical term "thermal sensitivity of sweet taste" is best explained by everyday experience: Warmer sugary solutions taste sweeter than cold ones.

In contrast to the well-defined role of TRPM5 in taste sensation, TRPM4 has more diverse roles. TRPM4 has been shown to play a role in $\mathrm{Ca}^{2+}$ oscillations in $\mathrm{T}$ cells [44], insulin secretion [13], and myogenic constriction of cerebral arteries [20], and it constitutes the $\mathrm{Ca}^{2+}$-activated nonselective $\mathrm{Ca}^{2+}$ channel in cardiac cells [68].

Despite their different physiological roles, TRPM4 and TRPM5 share activation by PIP $_{2}$. Both channels are activated by $\mathrm{Ca}^{2+}$ in excised patches, but their $\mathrm{Ca}^{2+}$ sensitivity decreases with time. This desensitization can be reversed by the application of $\mathrm{PIP}_{2}[50,65,114]$. PIP 2 activation of TRPM4 is much more prominent than that of TRPM5 [65]. The mechanism of activation by PIP $_{2}$ involves an increase in the $\mathrm{Ca}^{2+}$ sensitivity of TRPM4 and a dramatic shift of the voltage range for activation to negative potentials. Depletion of $\mathrm{PIP}_{2}$ from the cell via receptor stimulation, incubation of cells with wortmannin (an inhibitor of phosphatidylinositol 4-kinase, which delays $\mathrm{PIP}_{2}$ replenishment) application of the $\mathrm{PIP}_{2}$-scavenging agent poly-L-lysine, and overexpression of a $\mathrm{PIP}_{2}$-depleting enzyme 5ptase IV lead to a reduction in TRPM4 activity. The most striking proof is obtained in inside-out patches. Desensitization of the channel can be prevented or reversed when $\mathrm{PIP}_{2}$ is reapplied to the cytosolic side of excised patches. Recovery from desensitization can be achieved even in inside-out patches when Mg-ATP is added to the intracellular side during free perfusion, indicating that $\mathrm{PIP}_{2}$ is probably replenished via activation of lipid kinases. Because all these modulator effects prevail in excised inside-out patches, it is intriguing to speculate that $\mathrm{PIP}_{2}-$ modulating enzymes, such as lipid kinases (PIP4K and PIP5K), a $\mathrm{Ca}^{2+}$-dependent PLC, or phosphatidylinositol phosphatases form structural complexes with TRPM4 [65, 68] and other PIP $_{2}$-sensitive channels [34, 97].

The voltage sensor of the Aeropyrum pernix voltagegated potassium (KvAP) requires negatively charged phospholipids, such as phosphatidylglycerol, to maintain its gating properties $[46,90]$. It is likely that the two first arginines in the S4 region of the voltage sensor interact with the negatively charged phosphate head groups of the surrounding lipid. Interestingly, it has been shown for TRPM4 that the apparent gating charge of $\sim 0.7 \mathrm{e}$ under conditions of $\mathrm{PIP}_{2}$ depletion is reduced in the presence of $\mathrm{PIP}_{2}$ to $\sim 0.34$ [65]. A possible explanation could be the direct interaction between the voltage sensor and the negatively charged phosphate head group in $\mathrm{PIP}_{2}$ similarly to KvAP [90].

Table 4 Some important properties of members of the TRPP and TRPML families, as well as of TRPA1

\begin{tabular}{|c|c|c|c|}
\hline & $\begin{array}{l}\text { Selectivity } \\
P_{\mathrm{Ca}} / P_{\mathrm{Na}}\end{array}$ & Proposed activation mechanisms & $\begin{array}{l}\text { Effect of } \\
\text { phosphoinositides } \\
\text { (PIPs) }\end{array}$ \\
\hline $\begin{array}{l}\text { TRPML1, } \\
\text { ENSG00000090674 }\end{array}$ & $\begin{array}{l}\sim 1, \mathrm{H}^{+} \\
\text {permeable }\end{array}$ & Increased $\left[\mathrm{Ca}^{2+}\right]_{i}$, inhibited by proteolytic cleavage & ? \\
\hline $\begin{array}{l}\text { TRPML2, } \\
\text { ENSG00000153898 }\end{array}$ & n.d. & n.d. & $?$ \\
\hline $\begin{array}{l}\text { TRPML3, } \\
\text { ENSG00000055732 }\end{array}$ & n.d. & n.d. & $?$ \\
\hline $\begin{array}{l}\text { TRPP2, } \\
\text { ENSG00000118762 }\end{array}$ & $1-5$ & Mechanical stress, $\left[\mathrm{Ca}^{2+}\right]_{i}$ & $\mathrm{PIP}_{2}$ inhibits $[54]$ \\
\hline $\begin{array}{l}\text { TRPP3, } \\
\text { ENSG00000107593 }\end{array}$ & 4 & {$\left[\mathrm{Ca}^{2+}\right]_{I}$} & $?$ \\
\hline $\begin{array}{l}\text { TRPP5, } \\
\text { ENSG00000078795 }\end{array}$ & $1-5$ & {$\left[\mathrm{Ca}^{2+}\right]_{I}$} & $?$ \\
\hline $\begin{array}{l}\text { TRPA1, } \\
\text { ENSG00000104321 }\end{array}$ & $0.8-1.4$ & $\begin{array}{l}\text { Isothiocyanates, allicin, } \Delta^{9} \text {-tetrahydrocannabinol (THC), cinnamaldehyde, } \\
\text { prolonged noxious cold?, mechanical stress, voltage dependent?, }\left[\mathrm{Ca}^{2+}\right]_{i} \text { dependent, } \\
\text { OAG and arachidonic acid downstream of receptor-mediated PLC activation, } \\
\text { menthol?, thymol, carvacrol, acrolein, artemin (a neuronal survival factor), covalent } \\
\text { modification of N-terminal cysteines activates }\end{array}$ & $?$ \\
\hline
\end{tabular}

For references for channel names, numbering, and additional information, see legend to Table 1 
TRPM8 is a cold-sensitive ion channel expressed in sensory neurons. It is also activated by menthol $[55,74]$, depolarization [106], and $\mathrm{PIP}_{2}[48,86]$. These factors have a complex interplay in regulating this channel. Menthol sensitizes to cold [55], shifts the voltage dependence of the channel [106], and increases its apparent affinity for $\mathrm{PIP}_{2}$ [86]. Depolarization also increases sensitivity to $\mathrm{PIP}_{2}$ [86] and menthol [106]. Cold also shifts voltage dependence [106] and $\mathrm{PIP}_{2}$ sensitivity [86]. The channel displays an almost exclusive dependence on $\mathrm{PIP}_{2}$, chelating $\mathrm{PIP}_{2}$ in excised patches blocks channel activity completely [86]. Breaking down $\mathrm{PIP}_{2}$ in intact cells with rapamycin-inducible 5-phosphatase almost completely inhibits TRPM8 [104]. TRPM8, similar to TRPV1, undergoes desensitization in response to menthol and cold in the presence of extracellular $\mathrm{Ca}^{2+}$. It was proposed that the mechanism of this desensitization is the depletion of $\mathrm{PIP}_{2}$ via $\mathrm{Ca}^{2+}$-mediated activation of PLC (presumably a PLC $\delta$ isoform) [86]. PKC has also been shown to inhibit TRPM8 $[2,77]$. As PKC is also activated upon PLC activation, inhibition by PKC is also a feasible mechanism for desensitization. More experiments are needed to differentiate between these two alternative pathways. Menthol and the supercooling agent icilin have analgesic effects, which is mediated by the activation of TRPM8 [79]. A recent report showed that high concentrations of ethanol inhibit TRPM8 [4], and it was proposed that the mechanism of this inhibition is the interference with $\mathrm{PIP}_{2}$ activation.

TRPM8 is also expressed in the prostate, where neither cold temperatures nor cooling agents could serve as their physiological regulators. It has recently been shown that lysophospholipids (LPLs) also activate TRPM8 [103]. Whether the effects of LPLs depend on phosphoinositides needs to be determined in future experiments.

\section{TRPP2}

Polycystins are distant homologues of TRP channels. They were discovered by positional cloning of the gene responsible for the autosomal dominant form of PKD. PKD is one of the most common genetic disorders and a leading cause of end-stage renal disease worldwide. It was shown that polycystin 2 (PKD2, TRPP2) is inhibited by $\mathrm{PIP}_{2}$, and EGF activates PKD2 by relief from this inhibition via $\mathrm{PIP}_{2}$ hydrolysis [54]. For properties of the members of the TRPP and TRPML families, as well as TRPA1, see Table 4.

\section{Conclusions}

From the data reviewed here, it is tempting to assume that maybe the majority, if not all TRP channels are regulated by phosphoinositides. Only a few examples, however, have been studied in detail. Because we assume that this lipid regulation presents a general mechanism for modulation of TRP channel activity, some urgent questions have to be answered. First, a close correlation between $\mathrm{PIP}_{2}$ levels in the plasma membrane and channel activity has to be monitored in simultaneous measurements. Elegant tools are now available for such studies [96, 104]. Second, PIP 2 probably interacts with clusters of positive changes in the TRP channel proteins. Possible binding motifs for TRP channel interaction with $\mathrm{PIP}_{2}$ are pleckstrin homology domain-like sequences [65], which can be identified in all TRP proteins, or positively charged residues in the TRP domain [86]. However, the structure of a putative $\mathrm{PIP}_{2-}$ binding pocket is probably complex and still unknown. Furthermore, it has to be shown whether the effects of PIPs are really due to binding or due to charge compensation. Third, the functional impact of TRP channel modulation by $\mathrm{PIP}_{2}$ has to be shown in native cells under conditions of physiological stimulation, which would cause changes in $\mathrm{PIP}_{2}$ levels under in vivo conditions.

Acknowledgment We thank all members or our laboratories for always-helpful discussions. This work was supported by the Human Frontiers Science Programme (HFSP Research Grant Ref. RGP 32/ 2004), the Belgian Federal Government, the Flemish Government, the Onderzoeksraad KU Leuven (GOA 99/07, F.W.O. G.0214.99, F.W.O. G. 0136.00; F.W.O. G.0172.03, Interuniversity Poles of Attraction Program, Prime Ministers Office (IUAP; BN), and the American Heart Association, the Alexander and Alexandrine Sinsheimer Foundation, and the UMDNJ Foundation (TR).

\section{References}

1. Aarts M, Iihara K, Wei WL, Xiong ZG, Arundine M, Cerwinski W, MacDonald JF, Tymianski M (2003) A key role for TRPM7 channels in anoxic neuronal death. Cell 115:863-877

2. Abe J, Hosokawa H, Sawada Y, Matsumura K, Kobayashi S (2006) $\mathrm{Ca}^{2+}$-dependent PKC activation mediates mentholinduced desensitization of transient receptor potential M8. Neurosci Lett 397:140-144

3. Balla T (2001) Pharmacology of phosphoinositides, regulators of multiple cellular functions. Curr Pharm Des 7:475-507

4. Benedikt J, Teisinger J, Vyklicky L, Vlachova V (2006) Ethanol inhibits cold-menthol receptor TRPM8 by modulating its interaction with membrane phosphatidylinositol 4,5-bisphosphate. J Neurochem 100(1):211

5. Bezzerides VJ, Ramsey IS, Kotecha S, Greka A, Clapham DE (2004) Rapid vesicular translocation and insertion of TRP channels. Nat Cell Biol 6:709-720

6. Bhave G, Hu HJ, Glauner KS, Zhu W, Wang H, Brasier DJ, Oxford GS, Gereau RW (2003) Protein kinase C phosphorylation sensitizes but does not activate the capsaicin receptor transient receptor potential vanilloid 1 (TRPV1). Proc Natl Acad Sci USA 100:12480-12485

7. Brady JD, Rich ED, Martens JR, Karpen JW, Varnum MD, Brown RL (2006) Interplay between $\mathrm{PIP}_{3}$ and calmodulin regulation of olfactory cyclic nucleotide-gated channels. Proc Natl Acad Sci USA 103:15635-15640 
8. Brauchi S, Orta G, Salazar M, Rosenmann E, Latorre R (2006) A hotsensing cold receptor: C-terminal domain determines thermosensation in transient receptor potential channels. J Neurosci 26:4835-4840

9. Broad LM, Braun FJ, Lievremont JP, Bird GS, Kurosaki T, Putney JW Jr (2001) Role of the phospholipase C-inositol 1,4,5-trisphosphate pathway in calcium release-activated calcium current and capacitative calcium entry. J Biol Chem 276:15945-15952

10. Caterina MJ, Julius D (2001) The vanilloid receptor: a molecular gateway to the pain pathway. Annu Rev Neurosci 24:487-517

11. Caterina MJ, Schumacher MA, Tominaga M, Rosen TA, Levine JD, Julius D (1997) The capsaicin receptor: a heat-activated ion channel in the pain pathway. Nature 389:816-824

12. Chen X, Talley EM, Patel N, Gomis A, McIntire WE, Dong B, Viana F, Garrison JC, Bayliss DA (2006) Inhibition of a background potassium channel by $\mathrm{Gq}$ protein alpha-subunits. Proc Natl Acad Sci USA 103:3422-3427

13. Cheng H, Beck A, Launay P, Gross SA, Stokes AJ, Kinet JP, Fleig A, Penner R (2007) TRPM4 controls insulin secretion in pancreatic beta-cells. Cell Calcium 41(1):51-61

14. Chuang HH, Prescott ED, Kong H, Shields S, Jordt SE, Basbaum AI, Chao MV, Julius D (2001) Bradykinin and nerve growth factor release the capsaicin receptor from $\operatorname{PtdIns}(4,5) \mathrm{P}_{2}$ mediated inhibition. Nature 411:957-962

15. Clapham DE (2003) TRP channels as cellular sensors. Nature 426:517-524

16. Damak S, Rong M, Yasumatsu K, Kokrashvili Z, Perez CA, Shigemura N, Yoshida R, Mosinger B Jr, Glendinning JI, Ninomiya Y, Margolskee RF (2006) Trpm5 null mice respond to bitter, sweet, and umami compounds. Chem Senses 31:253-264

17. Delmas P, Coste B, Gamper N, Shapiro MS (2005) Phosphoinositide lipid second messengers: new paradigms for calcium channel modulation. Neuron 47:179-182

18. Dhaka A, Viswanath V, Patapoutian A (2006) Trp ion channels and temperature sensation. Annu Rev Neurosci 29:135-161

19. Du X, Zhang H, Lopes CM, Mirshahi T, Rohacs T, Logothetis DE (2004) Characteristic interactions with phosphatidylinositol 4,5-bisphosphate determine regulation of Kir channels by diverse modulators. J Biol Chem 279:37271-37281

20. Earley S, Waldron BJ, Brayden JE (2004) Critical role for transient receptor potential channel TRPM4 in myogenic constriction of cerebral arteries. Circ Res 95:922-929

21. Estacion M, Sinkins WG, Jones SW, Applegate MA, Schilling WP (2006) Human TRPC6 expressed in HEK 293 cells forms nonselective cation channels with limited $\mathrm{Ca}^{2+}$ permeability. J Physiol 572:359-377

22. Estacion M, Sinkins WG, Schilling WP (2001) Regulation of Drosophila transient receptor potential-like (TrpL) channels by phospholipase C-dependent mechanisms. J Physiol 530:1-19

23. Fan Z, Makielski JC (1997) Anionic phospholipids activate ATPsensitive potassium channels. J Biol Chem 272:5388-5395

24. Feske S, Gwack Y, Prakriya M, Srikanth S, Puppel SH, Tanasa B, Hogan PG, Lewis RS, Daly M, Rao A (2006) A mutation in Orail causes immune deficiency by abrogating CRAC channel function. Nature 441:179-185

25. Flockerzi V, Nilius B (eds) (2007) Transient receptor potential (TRP) channels. Springer, Berlin

26. Gwanyanya A, Sipido K, Vereecke J, Mubagwa K (2006) ATP- and $\mathrm{PIP}_{2}$-dependence of the magnesium-inhibited, TRPM7-like cation channel in cardiac myocytes. Am J Physiol Cell Physiol 291(4): C627-C635

27. Hardie RC (2003) Regulation of TRP channels via lipid second messengers. Annu Rev Physiol 65:735-759

28. Hardie RC (2007) TRP channels and lipids: from Drosophila to mammalian physiology. J Physiol 578(Pt 1):9-24
29. Hardie RC, Raghu P (2001) Visual transduction in Drosophila. Nature 413:186-193

30. Hilgemann DW, Ball R (1996) Regulation of cardiac $\mathrm{Na}^{+} / \mathrm{Ca}^{2+}$ exchange and $\mathrm{K}_{\mathrm{ATP}}$ potassium channels by $\mathrm{PIP}_{2}$. Science 273:956-959

31. Hilgemann DW, Feng S, Nasuhoglu C (2001) The complex and intriguing lives of $\mathrm{PIP}_{2}$ with ion channels and transporters. Sci STKE 2001:RE19

32. Hoenderop JG, Nilius B, Bindels RJ (2005) Calcium absorption across epithelia. Physiol Rev 85:373-422

33. Hofmann T, Chubanov V, Gudermann T, Montell C (2003) TRPM5 is a voltage-modulated and $\mathrm{Ca}^{2+}$-activated monovalent selective cation channel. Curr Biol 13:1153-1158

34. Huang CL, Feng S, Hilgemann DW (1998) Direct activation of inward rectifier potassium channels by $\mathrm{PIP}_{2}$ and its stabilization by $G \beta \gamma$. Nature 391:803-806

35. Huang GN, Zeng W, Kim JY, Yuan JP, Han L, Muallem S, Worley PF (2006) STIM1 carboxyl-terminus activates native SOC, I(crac) and TRPC1 channels. Nat Cell Biol 8:1003-1010

36. Inoue T, Heo WD, Grimley JS, Wandless TJ, Meyer T (2005) An inducible translocation strategy to rapidly activate and inhibit small GTPase signaling pathways. Nat Methods 2:415-418

37. Jordt SE, Bautista DM, Chuang HH, McKemy DD, Zygmunt PM, Hogestatt ED, Meng ID, Julius D (2004) Mustard oils and cannabinoids excite sensory nerve fibres through the TRP channel ANKTM1. Nature 427:260-265

38. Kiselyov K, Soyombo A, Muallem S (2007) TRPpathies. J Physiol 578(Pt 3):641-653

39. Kozak JA, Matsushita M, Nairn AC, Cahalan MD (2005) Charge screening by internal $\mathrm{pH}$ and polyvalent cations as a mechanism for activation, inhibition, and rundown of TRPM7/MIC channels. J Gen Physiol 126:499-514

40. Krapivinsky G, Mochida S, Krapivinsky L, Cibulsky SM, Clapham DE (2006) The TRPM7 ion channel functions in cholinergic synaptic vesicles and affects transmitter release. Neuron 52:485-496

41. Krauter T, Ruppersberg JP, Baukrowitz T (2001) Phospholipids as modulators of $\mathrm{K}_{\mathrm{ATP}}$ channels: distinct mechanisms for control of sensitivity to sulphonylureas, $\mathrm{K}^{+}$channel openers, and ATP. Mol Pharmacol 59:1086-1093

42. Kwon Y, Hofmann T, Montell C (2007) Integration of phosphoinositide- and calmodulin-mediated regulation of TRPC6. Mol Cell 25:491-503

43. Langeslag M, Clark K, Moolenaar WH, van Leeuwen FN, Jalink K (2007) Activation of TRPM7 channels by PLC-coupled receptor agonists. J Biol Chem 282(1):232-239

44. Launay P, Cheng H, Srivatsan S, Penner R, Fleig A, Kinet JP (2004) TRPM4 regulates calcium oscillations after $\mathrm{T}$ cell activation. Science 306:1374-1377

45. Launay P, Fleig A, Perraud AL, Scharenberg AM, Penner R, Kinet JP (2002) TRPM4 is a $\mathrm{Ca}^{2+}$-activated nonselective cation channel mediating cell membrane depolarization. Cell 109:397-407

46. Lee AG (2006) Ion channels: a paddle in oil. Nature 444:697

47. Lee J, Cha SK, Sun TJ, Huang C-L (2005) PIP 2 activates TRPV5 and releases its inhibition by intracellular $\mathrm{Mg}^{2+}$. J Gen Physiol 126:439-451

48. Liu B, Qin F (2005) Functional control of cold- and mentholsensitive TRPM8 ion channels by phosphatidylinositol 4,5bisphosphate. J Neurosci 25:1674-1681

49. Liu B, Zhang C, Qin F (2005) Functional recovery from desensitization of vanilloid receptor TRPV1 requires resynthesis of phosphatidylinositol 4,5-bisphosphate. J Neurosci 25:4835-4843

50. Liu D, Liman ER (2003) Intracellular $\mathrm{Ca}^{2+}$ and the phospholipid PIP2 regulate the taste transduction ion channel TRPM5. Proc Natl Acad Sci USA 100:15160-15165 
51. Lopes CMB, Zhang H, Rohacs T, Jin T, Logothetis DE (2002) Alterations in conserved Kir channel- $\mathrm{PIP}_{2}$ interactions underlie channelopathies. Neuron 34:933-944

52. Lopez JJ, Salido GM, Pariente JA, Rosado JA (2006) Interaction of STIM1 with endogenously expressed human canonical TRP1 upon depletion of intracellular $\mathrm{Ca}^{2+}$ stores. J Biol Chem 281:28254-28264

53. Lukacs V, Thyagarajan B, Balla A, Varnai P, Balla T, Rohacs T (2007) Dual regulation of TRPV1 by phosphatidylinositol 4,5bisphosphate, Biophysical Society Meeting Abstracts. Biophys J Suppl (abstract). Available at http://www.biophysics.org/ abstracts/

54. Ma R, Li WP, Rundle D, Kong J, Akbarali HI, Tsiokas L (2005) PKD2 functions as an epidermal growth factor-activated plasma membrane channel. Mol Cell Biol 25:8285-8298

55. McKemy DD, Neuhausser WM, Julius D (2002) Identification of a cold receptor reveals a general role for TRP channels in thermosensation. Nature 416:52-58

56. McLaughlin S (2006) Cell biology. Tools to tamper with phosphoinositides. Science 314:1402-1403

57. McLaughlin S, Murray D (2005) Plasma membrane phosphoinositide organization by protein electrostatics. Nature 438:605-611

58. Mohapatra DP, Nau C (2005) Regulation of $\mathrm{Ca}^{2+}$-dependent desensitization in the vanilloid receptor TRPV1 by calcineurin and cAMP-dependent protein kinase. J Biol Chem 280:13424-13432

59. Monteilh-Zoller MK, Hermosura MC, Nadler MJ, Scharenberg AM, Penner R, Fleig A (2003) TRPM7 provides an ion channel mechanism for cellular entry of trace metal ions. J Gen Physiol 121:49-60

60. Montell C (2005) The TRP superfamily of cation channels. Sci STKE 2005:RE3

61. Montell C (2006) An exciting release on TRPM7. Neuron 52:395-397

62. Nakanishi S, Catt KJ, Balla T (1995) A wortmannin-sensitive phosphatidylinositol 4-kinase that regulates hormone-sensitive pools of inositolphospholipids. Proc Natl Acad Sci USA 92:5317-5321

63. Nilius B (2003) From TRPs to SOCs, CCEs, and CRACs: consensus and controversies. Cell Calcium 33:293-298

64. Nilius B, Mahieu F (2006) A road map for TR(I)Ps. Mol Cell 22:297-307

65. Nilius B, Mahieu F, Prenen J, Janssens A, Owsianik G, Vennekens R, Voets T (2006) The $\mathrm{Ca}^{2+}$-activated cation channel TRPM4 is regulated by phosphatidylinositol 4,5-biphosphate. EMBO J 25:467-478

66. Nilius B, Owsianik G, Voets T, Peters JA (2007) Transient receptor potential channels in disease. Physiol Rev 87:165-217

67. Nilius B, Talavera K, Owsianik G, Prenen J, Droogmans G, Voets T (2005) Gating of TRP channels: a voltage connection? J Physiol 567:35-44

68. Nilius B, Vennekens R (2006) From cardiac cation channels to the molecular dissection of the transient receptor potential channel TRPM4. Pflugers Arch 453(3):313-321

69. Nilius B, Voets T (2005) TRP channels: a TR(I)P through a world of multifunctional cation channels. Pflugers Arch 451:1-10

70. Nilius B, Voets T, Peters J (2005) TRP channels in disease. Sci STKE 2005:RE8

71. Owsianik G, Talavera K, Voets T, Nilius B (2006) Permeation and selectivity of TRP channels. Annu Rev Physiol 68:685-717

72. Ozaki S, Dewald DB, Shope JC, Chen J, Prestwich GD (2000) Intracellular delivery of phosphoinositides and inositol phosphates using polyamine carriers. Proc Natl Acad Sci USA 97:11286-11291

73. Pedersen SF, Owsianik G, Nilius B (2005) TRP channels: an overview. Cell Calcium 38:233-252
74. Peier AM, Moqrich A, Hergarden AC, Reeve AJ, Andersson DA, Story GM, Earley TJ, Dragoni I, McIntyre P, Bevan S, Patapoutian A (2002) A TRP channel that senses cold stimuli and menthol. Cell 108:705-715

75. Perez CA, Huang L, Rong M, Kozak JA, Preuss AK, Zhang H, Max M, Margolskee RF (2002) A transient receptor potential channel expressed in taste receptor cells. Nat Neurosci 5:1169-1176

76. Prawitt D, Monteilh-Zoller MK, Brixel L, Spangenberg C, Zabel B, Fleig A, Penner R (2003) TRPM5 is a transient $\mathrm{Ca}^{2+}$-activated cation channel responding to rapid changes in $\left[\mathrm{Ca}^{2+}\right]_{\mathrm{i}}$. Proc Natl Acad Sci USA 100:15166-15171

77. Premkumar LS, Raisinghani M, Pingle SC, Long C, Pimentel F (2005) Downregulation of transient receptor potential melastatin 8 by protein kinase $\mathrm{C}$-mediated dephosphorylation. J Neurosci $25: 11322-11329$

78. Prescott ED, Julius D (2003) A modular PIP 2 binding site as a determinant of capsaicin receptor sensitivity. Science 300:1284-1288

79. Proudfoot CJ, Garry EM, Cottrell DF, Rosie R, Anderson H, Robertson DC, Fleetwood-Walker SM, Mitchell R (2006) Analgesia mediated by the TRPM8 cold receptor in chronic neuropathic pain. Curr Biol 16:1591-1605

80. Putney JW Jr (1990) Capacitative calcium entry revisited. Cell Calcium 11:611-624

81. Putney JW (2005) Physiological mechanisms of TRPC activation. Pflugers Arch 451:29-34

82. Rohacs T (2007) Regulation of TRP channels by PIP $_{2}$. Pflugers Arch 453:753-762

83. Rohacs T, Chen J, Prestwich GD, Logothetis DE (1999) Distinct specificities of inwardly rectifying $\mathrm{K}^{+}$channels for phosphoinositides. J Biol Chem 274:36065-36072

84. Rohacs T, Lopes C, Mirshahi T, Jin T, Zhang H, Logothetis DE (2002) Assaying phosphatidylinositol bisphosphate regulation of potassium channels. Methods Enzymol 345:71-92

85. Rohacs T, Lopes CM, Jin T, Ramdya PP, Molnar Z, Logothetis DE (2003) Specificity of activation by phosphoinositides determines lipid regulation of Kir channels. Proc Natl Acad Sci USA 100:745-750

86. Rohacs T, Lopes CMB, Michailidis I, Logothetis DE (2005) $\mathrm{PI}(4,5) \mathrm{P}_{2}$ regulates the activation and desensitization of TRPM 8 channels through the TRP domain. Nat Neurosci 8:626-634

87. Runnels LW, Yue L, Clapham DE (2002) The TRPM7 channel is inactivated by $\mathrm{PIP}_{2}$ hydrolysis. Nat Cell Biol 4:329-336

88. Sahni J, Nelson B, Scharenberg AM (2007) SLC41A2 encodes a plasma membrane $\mathrm{Mg}^{2+}$ transporter. Biochem J 401(2):505-513

89. Sawynok J (2003) Topical and peripherally acting analgesics. Pharmacol Rev 55:1-20

90. Schmidt D, Jiang QX, MacKinnon R (2006) Phospholipids and the origin of cationic gating charges in voltage sensors. Nature 444:775-779

91. Schmitz C, Perraud AL, Johnson CO, Inabe K, Smith MK, Penner R, Kurosaki T, Fleig A, Scharenberg AM (2003) Regulation of vertebrate cellular $\mathrm{Mg}^{2+}$ homeostasis by TRPM7. Cell 114:191-200

92. Shyng SL, Barbieri A, Gumusboga A, Cukras C, Pike L, Davis JN, Stahl PD, Nichols CG (2000) Modulation of nucleotide sensitivity of ATP-sensitive potassium channels by phosphatidylinositol-4phosphate 5-kinase. Proc Natl Acad Sci USA 97:937-941

93. Stein AT, Ufret-Vincenty CA, Hua L, Santana LF, Gordon SE (2006) Phosphoinositide 3-Kinase binds to TRPV1 and mediates NGF-stimulated TRPV1 trafficking to the plasma membrane. J Gen Physiol 128:509-522

94. Su LT, Agapito MA, Li M, Simonson WT, Huttenlocher A, Habas R, Yue L, Runnels LW (2006) TRPM7 regulates cell adhesion by controlling the calcium-dependent protease calpain. J Biol Chem 281:11260-11270 
95. Suh BC, Hille B (2005) Regulation of ion channels by phosphatidylinositol 4,5-bisphosphate. Curr Opin Neurobiol 15:370-378

96. Suh BC, Inoue T, Meyer T, Hille B (2006) Rapid chemically induced changes of $\operatorname{PtdIns}(4,5) \mathrm{P}_{2}$ gate $\mathrm{KCNQ}$ ion channels. Science 314:1454-1457

97. Sui JL, Petit Jacques J, Logothetis DE (1998) Activation of the atrial $\mathrm{K}_{\mathrm{ACh}}$ channel by the betagamma subunits of $\mathrm{G}$ proteins or intracellular $\mathrm{Na}^{+}$ions depends on the presence of phosphatidylinositol phosphates. Proc Natl Acad Sci USA 95:1307-1312

98. Takezawa R, Schmitz C, Demeuse P, Scharenberg AM, Penner R, Fleig A (2004) Receptor-mediated regulation of the TRPM7 channel through its endogenous protein kinase domain. Proc Natl Acad Sci USA 101:6009-6014

99. Talavera K, Yasumatsu K, Voets T, Droogmans G, Shigemura N, Ninomiya Y, Margolskee RF, Nilius B (2005) Heat activation of TRPM5 underlies thermal sensitivity of sweet taste. Nature 438:1022-1025

100. Tominaga M, Caterina MJ, Malmberg AB, Rosen TA, Gilbert H, Skinner K, Raumann BE, Basbaum AI, Julius D (1998) The cloned capsaicin receptor integrates multiple pain-producing stimuli. Neuron 21:531-543

101. Tominaga M, Wada M, Masu M (2001) Potentiation of capsaicin receptor activity by metabotropic ATP receptors as a possible mechanism for ATP-evoked pain and hyperalgesia. Proc Natl Acad Sci USA 98:6951-6956

102. Tseng PH, Lin HP, Hu H, Wang C, Zhu MX, Chen CS (2004) The canonical transient receptor potential 6 channel as a putative phosphatidylinositol 3,4,5-trisphosphate-sensitive calcium entry system. Biochemistry 43:11701-11708

103. Vanden Abeele F, Zholos A, Bidaux G, Shuba Y, Thebault S, Beck B, Flourakis M, Panchin Y, Skryma R, Prevarskaya N (2006) iPLA2-dependent gating of TRPM8 by lysophospholipids. J Biol Chem 281(52):40174-40182

104. Varnai P, Thyagarajan B, Rohacs T, Balla T (2006) Rapidly inducible changes in phosphatidylinositol 4,5-bisphosphate levels influence multiple regulatory functions of the lipid in intact cells. J Cell Biol 175:377-382
105. Vig M, Peinelt C, Beck A, Koomoa DL, Rabah D, KoblanHuberson M, Kraft S, Turner H, Fleig A, Penner R, Kinet JP (2006) CRACM1 is a plasma membrane protein essential for store-operated $\mathrm{Ca}^{2+}$ entry. Science 312:1220-1223

106. Voets T, Droogmans G, Wissenbach U, Janssens A, Flockerzi V, Nilius B (2004) The principle of temperature-dependent gating in cold- and heat-sensitive TRP channels. Nature 430:748-754

107. Voets T, Janssens A, Prenen J, Droogmans G, Nilius B (2003) $\mathrm{Mg}^{2+}$-dependent gating and strong inward rectification of the cation channel TRPV6. J Gen Physiol 121:245-260

108. Voets T, Talavera K, Owsianik G, Nilius B (2005) Sensing with TRP channels. Nat Chem Biol 1:85-92

109. Xu H, Delling M, Jun JC, Clapham DE (2006) Oregano, thyme and clove-derived flavors and skin sensitizers activate specific TRP channels. Nat Neurosci 9:628-635

110. Zhang H, Craciun LC, Mirshahi T, Rohacs T, Lopes CMB, Jin T, Logothetis DE (2003) $\mathrm{PIP}_{2}$ activates KCNQ channels and its hydrolysis underlies receptor-mediated inhibition of $\mathrm{M}$ currents. Neuron 37:963-975

111. Zhang H, Xu Y, Zhang Z, Liman ER, Prestwich GD (2006) Synthesis and biological activity of phospholipase C-resistant analogues of phosphatidylinositol 4,5-bisphosphate. J Am Chem Soc 128:5642-5643

112. Zhang SL, Yu Y, Roos J, Kozak JA, Deerinck TJ, Ellisman MH, Stauderman KA, Cahalan MD (2005) STIM1 is a $\mathrm{Ca}^{2+}$ sensor that activates CRAC channels and migrates from the $\mathrm{Ca}^{2+}$ store to the plasma membrane. Nature 437:902-905

113. Zhang Y, Hoon MA, Chandrashekar J, Mueller KL, Cook B, Wu D, Zuker CS, Ryba NJ (2003) Coding of sweet, bitter, and umami tastes: different receptor cells sharing similar signaling pathways. Cell 112:293-301

114. Zhang Z, Okawa H, Wang Y, Liman ER (2005) Phosphatidylinositol 4,5-bisphosphate rescues TRPM4 channels from desensitization. J Biol Chem 280:39185-39192

115. Zhu X, Jiang M, Peyton M, Boulay G, Hurst R, Stefani E, Birnbaumer L (1996) trp, a novel mammalian gene family essential for agonist-activated capacitative $\mathrm{Ca}^{2+}$ entry. Cell $85: 661-671$ 